\title{
Evaluation of Mercury Stress in Plants from the Almadén Mining District by Analysis of Phytochelatins and Their $\mathrm{Hg}$ Complexes
}

\author{
Àngela Dago, ${ }^{\dagger}$ Inmaculada González, ${ }^{\dagger}$ Cristina Ariño, ${ }^{* \dagger}{ }^{\dagger}$ Alba Martínez-Coronado, ${ }^{\ddagger}$ Pablo Higueras, ${ }^{\ddagger}$ \\ José Manuel Díaz-Cruz, ${ }^{\dagger}$ and Miquel Esteban ${ }^{\dagger}$

\begin{abstract}
${ }^{\dagger}$ Departament de Química Analítica, Facultat de Química, Universitat de Barcelona, Martí i Franquès, 1-11, 08028 Barcelona, Barcelona, Spain

${ }^{*}$ Instituto de Geología Aplicada, Escuela de Ingeniería Minera e Industrial de Almadén, Universidad de Castilla-La Mancha, Plaza M.
\end{abstract} \\ Meca 1, 13400 Almadén, Ciudad Real, Spain
}

\begin{abstract}
To evaluate plant response to $\mathrm{Hg}$ stress, glutathione, phytochelatins, and their $\mathrm{Hg}$ complexes were analyzed using HPLC with amperometric detection in samples of Asparagus acutifolius grown in the Almadén mining district (Ciudad Real, Spain), one of the most Hg-contaminated sites in the world. Soils of the Almadén mining district, and specifically from the Almadenejos zone, are highly contaminated, with some zones having values above $4,000 \mu \mathrm{g} \mathrm{Hg} \mathrm{g}^{-1}$ soil. Although soils have an extremely high concentration of mercury, generally less than $2 \%$ is available for plants, as is shown by various soil extractions simulating bioavailability. In plants, $\mathrm{Hg}$ concentration increases depending on the content of $\mathrm{Hg}$ in soils. In addition, $\mathrm{Hg}$ levels in roots are higher than in aerial parts, which is a

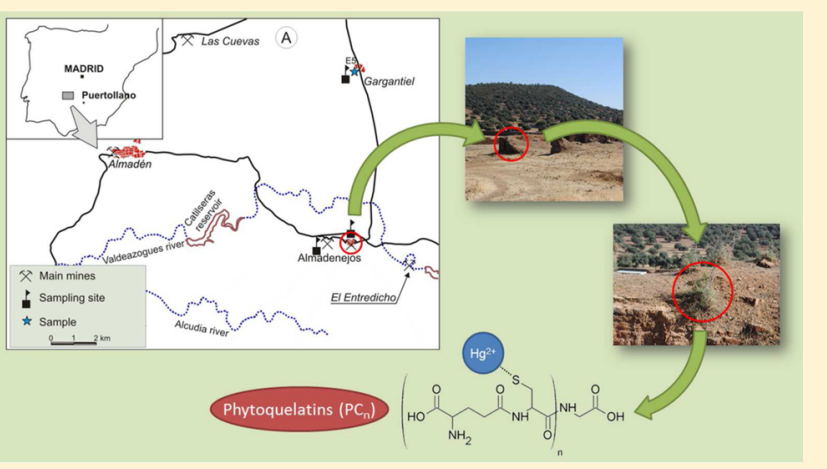
strategy of plants for protecting their more sensitive aerial parts from the deleterious effects of metal stress. The total content of phytochelatins (PCs) and their complexes are directly related with the amount of mercury in soils. These findings highlight the important role of thiol compounds and their metal complexes in capturing and fixing $\mathrm{Hg}$ from soils, giving plants the capacity to deal with the heavy metal toxicity of polluted soils.
\end{abstract}

\section{INTRODUCTION}

The development and growth of mining, metallurgy, and industrial activities has increased the concentration of heavy metals in the environment, thus exposing animals and plants to high concentrations of these contaminants. Since plants are the main source of human food, the presence of heavy metals in them is of great interest. Plants absorb metals from soils, water, and air. However, the chief source of metal absorption is soil. Uptake from it depends not only on the total content of the respective metals but also on their accessibility to roots and transfer across the soil-root interface. The total amount of metal in a soil is, in turn, affected by the inherent natural resources of the particular area, in addition to the agricultural and industrial activities. ${ }^{1}$

Among the toxic trace metals, mercury $(\mathrm{Hg})$ is one of the most hazardous environmental pollutants. ${ }^{2-5}$ The toxicity and environmental mobility of mercury compounds are closely related to their chemical form. Cinnabar and other mercury sulfides, mercury oxides, metallic mercury, and organo-mercury compounds are the most common mercury forms found near mercury mining sites. Moreover, total concentrations of metals in soils are not a good indicator of phytoavailability, or a good tool for potential risk assessment, due to the varied and complex distribution patterns of metals among various chemical species or solid phases.
The Almadén district (Spain) is known for the largest deposits of mercury in the world yet discovered. ${ }^{6,7}$ Because of this, the Almadén district can be regarded as one of the most Hg-contaminated places on Earth. ${ }^{8}$ The Almadén district covers an area of about $300 \mathrm{~km}^{2}$ and comprises many mercury mines that are now inactive, but in their almost 2000 years of activity have produced about a third of the mercury consumed by mankind. ${ }^{6}$ Almadenejos village owes its origin to the discovery and exploitation of $\mathrm{Hg}$ mines near the village, including the nearby "Vieja Concepción" and "Nueva Concepción" mines. ${ }^{6}$ Almadenejos is also the site of a historic metallurgical enclosure that housed the furnaces where $\mathrm{Hg}$ was extracted from cinnabar ores. This old metallurgical precinct, known as "Cerco de Almadenejos", can be regarded as one of the most contaminated sites in the whole Almadén district, as seen in its soils, water, and sediments. ${ }^{9-11}$

Knowledge of the physiological and molecular mechanisms that plants have to degrade or eliminate pollutants in contaminated soils which are troubling for human health is of great interest. ${ }^{12}$ Plants' main mechanism for fighting against

Received: July 15, 2013

Revised: March 24, 2014

Accepted: May 2, 2014

Published: May 2, 2014 
metal toxicity is phytochelatin synthesis. Phytochelatins (PCs) are small, cysteine-rich peptides that are synthesized in the cytosol in response to heavy metal stress. Metal-PC complexes are formed and sequestered in vacuoles via transport across the tonoplast where their toxicity is less concerning. ${ }^{13,14}$ Thus, PCs are assumed to be involved in the accumulation, detoxification, and metabolism of heavy metal ions in plant cells. ${ }^{15}$ The general structure of this set of peptides is $(\gamma \text {-Glu-Cys })_{n}$-Gly $(n=$ 2 to 5). ${ }^{16,17}$ Glutathione serves as the substrate of PC biosynthesis through the transpeptidation of the $\gamma$-Glu-Cys moiety of GSH onto a second GSH to form $\mathrm{PC}_{2}$ or onto a PC molecule to produce an $n+1$ oligomer. For these reasons, the study of PC content in plants is highly relevant, as PCs could be used as indicators of metal pollution.

Of all the studies of the Almadén mining district, none evaluates the heavy metal stress caused in plants by the high $\mathrm{Hg}$ concentrations found in soils, sediments, water, or air. However, several researchers have studied mercury distribution in the environment. Higueras et al. ${ }^{9}$ and Martínez-Coronado et al. ${ }^{11}$ emphasized the high amounts of $\mathrm{Hg}$ found in soils and postulate the possible sources of $\mathrm{Hg}$. Ferrara et al. ${ }^{18}$ and Higueras et al. ${ }^{19}$ analyzed the atmospheric $\mathrm{Hg}$ and determined the main emission sources and $\mathrm{Hg}$ fluxes over Almadén village. The aquatic environment has also been analyzed by Berzas Nevado et al., ${ }^{20}$ Gray et al., ${ }^{10}$ and Rodríguez MartínDoimeadios et al., ${ }^{21}$ who determined $\mathrm{Hg}$ in waters, sediments, and bivalves. A reconnaissance survey of $\mathrm{Hg}$ in sediments, soil, and water and a comparison with other mining districts by Higueras et al. ${ }^{8}$ reached the main conclusion that the Almaden mining district is the most highly $\mathrm{Hg}$-contaminated site in the world. A complete analysis of the $\mathrm{Hg}$ concentration in many plants of the Almadén mining district was published by Millán et al. $^{22}$ and Molina et al., ${ }^{23}$ who pointed out the differing behavior of diverse plants in mercury uptake. Another study determined $\mathrm{Hg}$ in plants grown in the laboratory using Almadén soil and compared the results with plants grown in perlite:vermiculite soil spiked with $\mathrm{Hg}^{24}$ In this article, a decrease in mercury accumulation was observed in Almadén soil, which was attributed to the low bioavailability of mercury in this soil. However, PCs and Hg-PC, as markers for heavy metal stress, were not evaluated in any of these studies. Nevertheless, in the literature there are some studies of the effect of $\mathrm{Hg}$ in plants through examination of PC synthesis. In these studies, PCs are mainly determined by HPLC coupled with mass spectrometry, ${ }^{25-27}$ although in some cases fluorescence $^{28}$ or absorbance detection ${ }^{29,30}$ are used. In our research group, the interactions between $\mathrm{Hg}$ and PCs in several in vitro experiments were studied with electroanalytical techniques in either static experiments ${ }^{31,32}$ or chromatographic separations ${ }^{33,34}$ showing very low detection limits. Moreover, in previous studies Hordeum vulgare plants cultured with mercury or other heavy metals have been considered for the determination of the induced PCs and the $\mathrm{Hg}$-PC complexes formed with HPLC with amperometric detection. ${ }^{35,36}$

For the present study, wild asparagus (Asparagus acutifolius) was selected, because it is a typical evergreen perennial plant that grows naturally in the mining zone of the Almaden district. $^{23}$ Several zones with different $\mathrm{Hg}$ concentrations were chosen, and aerial and underground parts of plants from these zones were analyzed separately to determine the total concentration of $\mathrm{Hg}$, as well as the concentrations of PCs and their $\mathrm{Hg}$ complexes. The correlation with the $\mathrm{Hg}$ concentration of the source soil was also looked at, including both total $\mathrm{Hg}$ concentration and the extractable fractions. Therefore, the aims of this study were to examine whether natural plants, grown in the Almadén district, accumulated mercury from the contaminated soil and to analyze these samples with HPLC-amperometric detection, considering the induced PCs and $\mathrm{Hg}$-PC complexes formed in both aerial parts and roots, in order to correlate these species with the mercury found in soils and to find out more about plants' PC synthesis for dealing with metal toxicity.

\section{EXPERIMENTAL SECTION}

2.1. Plant and Soil Sampling. Samples of soils and plants were collected in four areas with different $\mathrm{Hg}$ content in Almadenejos: (E1) above the ruins of a furnace in the Almadenejos precinct, where the ore was heated to temperatures over $300{ }^{\circ} \mathrm{C}$; (E2) next to the ruins of a furnace, where $\mathrm{Hg}$ vapor was condensed in the pottery lines; (E3) at the entrance of the "Nueva Concepción" mine; (E4) the wall limiting the old metallurgical precinct called "Cerco de Almadenejos" in the closest area to the village. Other samples (E5) were collected in Gargantiel, a village $9 \mathrm{~km}$ from Almadenejos, which we used as a blank site, as there were low concentrations of mercury in the local soil. The location of the individual samples was recorded with a portable Global Position System (GPS) (Figure 1).

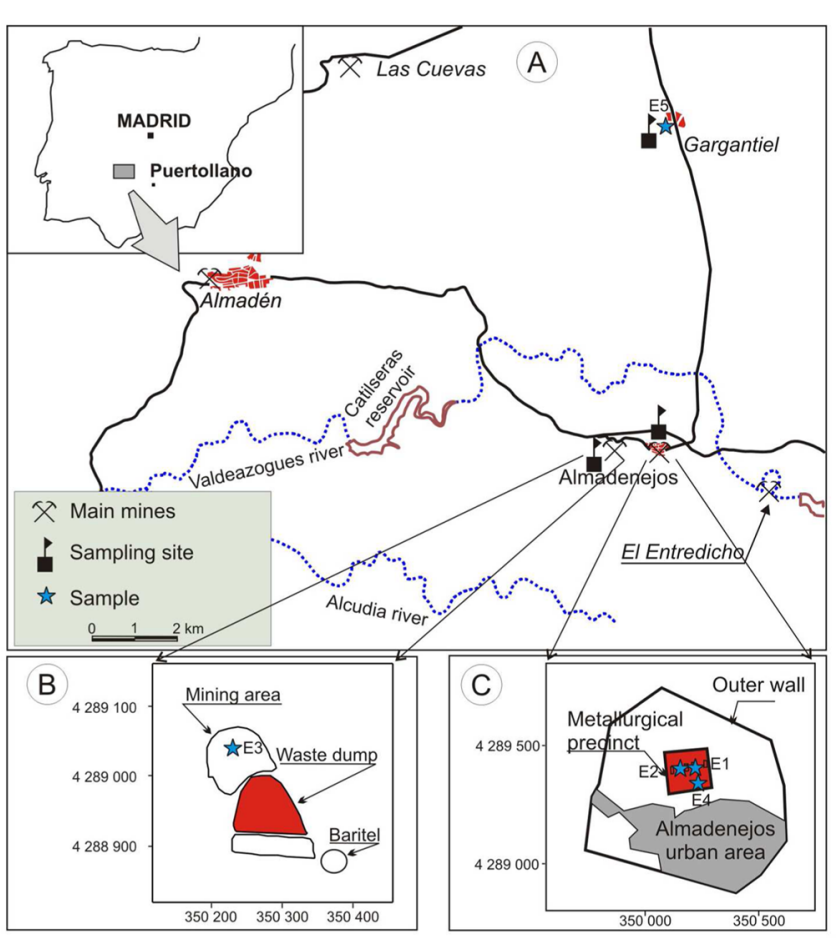

Figure 1. Sketch map of the area. A) General area; B) Nueva Concepción area, Baritel is an old type of mine shaft building; C) Almadenejos area. Numbers in the axis of B and C are UTM VGS 84 coordinates.

We also performed the edaphic characterization of soil samples, including the determinations of the main parameters relevant to mining areas: electrical conductivity (EC), $\mathrm{pH}$, and organic matter (OM) content. $\mathrm{EC}$ and $\mathrm{pH}$ were measured on soil suspensions: samples $(10 \mathrm{~g})$ were homogenized in $25 \mathrm{~mL}$ of ultrapure water and subjected to a process of mechanical stirring for $120 \mathrm{~min}$ with a Unitronic 320 OR stirring bath to 
homogenize and reach an equilibrium. ${ }^{37}$ Then, $\mathrm{pH}$ and EC were determined with a GLP Crison $\mathrm{pH}$ meter and a GLP 32 Crison conductivity meter. $\mathrm{OM}$ was determined by following the Walkley and Black method. ${ }^{38}$ Table 1 shows the results of these measurements, emphasizing the physical and chemical similarities of these soils.

Table 1. Edaphic Characterization of Soil Samples from the Different Sampling Sites

\begin{tabular}{|c|c|c|c|c|}
\hline sampling site & $\mathrm{pH}$ & $\begin{array}{l}\text { electrical } \\
\text { conductivity } \\
\left(\mu \mathrm{S} \mathrm{cm}^{-1}\right)\end{array}$ & $\begin{array}{l}\text { organic } \\
\text { matter } \\
(\%)\end{array}$ & $\begin{array}{l}\text { soil } \\
\text { texture }\end{array}$ \\
\hline $\begin{array}{l}\text { E1. Almadenejos precinct } \\
\text { (above the furnace ruins) }\end{array}$ & 7.66 & 214 & 4.35 & loam \\
\hline $\begin{array}{l}\text { E2. Almadenejos precinct } \\
\text { (next to the furnace } \\
\text { ruins) }\end{array}$ & 7.38 & 162 & 4.14 & $\begin{array}{l}\text { sandy- } \\
\text { loam }\end{array}$ \\
\hline E3. Mine entrance & 7.67 & 170 & 6.02 & $\begin{array}{l}\text { sandy- } \\
\text { loam }\end{array}$ \\
\hline $\begin{array}{l}\text { E4. Almadenejos precinct } \\
\text { (wall) }\end{array}$ & 7.36 & 307 & 6.67 & $\begin{array}{l}\text { loamy- } \\
\text { sand }\end{array}$ \\
\hline E5. Gargantiel & 5.72 & 135 & 5.61 & $\begin{array}{l}\text { sandy- } \\
\text { loam }\end{array}$ \\
\hline
\end{tabular}

2.2. Sample Preparation. Once plant samples had been collected (several portions of aerial parts and roots of different plants from each sampling zone), they were taken to the laboratory, cleaned with ultrapure filtered water, and accurately cut into small pieces. Plants were frozen with liquid nitrogen separating the aerial parts of the plant (stems and leaves) from the underground one (roots). Afterward, samples were ground with liquid nitrogen in a mortar and stored at $-80{ }^{\circ} \mathrm{C}$ until analysis.

Soils were ground and homogenized with an agate mortar and pestle and sieved through mesh to obtain a particle size lower than $100 \mu \mathrm{m}$.

2.3. SPE Procedure and HPLC-ED Analysis for the Determination of PCs and Their Hg Complexes in Plant Samples. Prior to HPLC analysis, water extraction and then a cleanup step in solid phase extraction (SPE) cartridges were performed. For this purpose, $50 \mathrm{mg}$ of fresh sample were mixed with $250 \mu \mathrm{L}$ of ultrapure filtered water at $1,500 \mathrm{rpm}$ for $1 \mathrm{~h}$ in an Eppendorf MixMate (Hamburg, Germany). For the preconcentration and cleanup of the samples, DSC-18 SPE cartridges (Supelco, Bellefonte, PA, USA) were used in a Visiprep SPE Vacuum Manifold (Supelco). For the evaporation under nitrogen stream, a Visidry drying attachment was used. Prior to the cleanup procedure, samples were filtered through $0.45 \mu \mathrm{m}$ Nylon filter discs (Osmonics, Minnetonka, MN, USA) and $\mathrm{pH}$ was adjusted to 2.00 with trifluoroacetic acid (TFA). SPE tube packing was conditioned by rinsing with $2 \mathrm{~mL}$ of methanol and $2 \mathrm{~mL}$ of $0.1 \%$ TFA in water. Then, the sample was accurately transferred to the tube and washed with $1 \mathrm{~mL}$ of $0.1 \%$ TFA in water. In this step, weakly retained materials were removed. Finally, the relevant compounds were eluted with 2 $\mathrm{mL}$ of methanol, leaving behind any impurities not removed in the wash step. After this, the eluent was evaporated and then reconstituted in $100 \mu \mathrm{L}$ of ultrapure filtered water. This cleanup procedure eliminates many irrelevant signals that appear at low retention times and provides clearer chromatograms. An Agilent 1100 chromatographic system (Agilent, Santa Clara, CA, USA) was used with an Ascentis C18 column (Supelco), particle size $5 \mu \mathrm{m}, 25 \mathrm{~cm} \times 4.6 \mathrm{~mm}$ column. The mobile phase consisted of $0.1 \%$ TFA in ultrapure filtered water $\mathrm{pH}=2.00$ and $0.1 \%$ TFA in acetonitrile. Separation was performed with gradient elution, as described in Dago et al. ${ }^{34}$ The electrochemical detector (ED), consisting of a flow cell (BAS, West Lafayette, IN, USA) and an Autolab PGSTAT-12 (Eco Chemie, Utrecht, The Netherlands), was coupled at the end of the column. The flow cell consisted of a glassy carbon working electrode (BAS) whose surface was polished daily, a stainless steel auxiliary electrode, and an $\mathrm{Ag} / \mathrm{AgCl}\left(\mathrm{NaCl} 3 \mathrm{~mol} \mathrm{~L}^{-1}\right)$ reference electrode. The optimized potential for the working electrode was $1.2 \mathrm{~V}$. The complete HPLC-amperometric detection procedure, along with its calibration functions and its limits of detection and quantification, is given in Dago et $\mathrm{al}^{34}$

2.4. Analysis of $\mathrm{Hg}$ Concentration in Plants. To determine $\mathrm{Hg}$ concentration in roots and aerial parts, $50 \mathrm{mg}$ of fresh sample were transferred into glass reactors with $2 \mathrm{~mL}$ of $65 \% \mathrm{HNO}_{3}$. Digestion was conducted for $1 \mathrm{~h}$ at $90{ }^{\circ} \mathrm{C}$. Cooled digested extracts were diluted with $20 \mathrm{~mL}$ of ultrapure filtered water. The appropriate volume of these solutions was then diluted with $1 \% \mathrm{HNO}_{3}$ with the addition of $\mathrm{KMnO}_{4}$ to stabilize $\mathrm{Hg}(\mathrm{II})$ and $2 \%$ rhodium as internal standard. All samples were analyzed in triplicate by an ICP-MS Elan-6000 (PerkinElmer, Waltham, MA, USA). Hg concentration in procedure blanks and in all reagents were always below the detection limits.

2.5. Analysis of $\mathrm{Hg}$ Concentration in Soils. Total $\mathrm{Hg}$ concentration in soils was measured with a LUMEX RA-915+ analyzer (Lumex, Saint Petersburg, Russia) with the RP-91C pyrolysis attachment (Lumex). In this equipment, based on Zeeman atomic absorption spectrometry, the sample is vaporized and mercury compounds are fully decomposed by heating to $800{ }^{\circ} \mathrm{C}$, whereas organic compounds and carbon particles are catalytically transformed to carbon dioxide and water. $^{11,23}$ Quality control is accomplished by analyzing equipment blanks $\left(<0.002 \mathrm{mg} \mathrm{kg}{ }^{-1}\right)$, duplicate samples (Relative Standard Deviation: $1.51 \%$ ), and the certified reference material NIST SRM 2710 (32.6 mg kg-1 $\mathrm{Hg}$ ), obtaining precision (1.23\%) and accuracy (99.32\%) for total mercury in solid samples under the conditions of these analyses.

Different extraction procedures were applied to each soil sample in order to determine the extractable fractions of $\mathrm{Hg}$. These methods are summarized as follows:

a) Organic mercury was determined as described in Válega et al., ${ }^{39}$ in which a soil sample was first treated with acid leaching $\left(\mathrm{KBr} / \mathrm{H}_{2} \mathrm{SO}_{4} / \mathrm{CuSO}_{4}\right)$, then by the extraction of the organic mercury halide with toluene and back-extracted with an aqueous sodium thiosulfate solution. Extracted solutions of each soil were analyzed directly by atomic absorption spectrometry (AAS) with thermal decomposition, using an Advanced Mercury Analyzer AMA-254 (Leco, St. Joseph, MI, USA). This simple methodology is based on thermal decomposition of the sample and collection of the mercury vapor on a gold amalgamator.

b) The United States Geological Survey (USGS) extraction method proposed by Hageman ${ }^{40}$ simulates the leachability and the chemical reactions that occur when geological materials are in contact with water. For this purpose, $5 \mathrm{~g}$ of soil were mixed with deionized water at a 1:20 ratio for $2 \mathrm{~h}$ at $50 \mathrm{rpm}$ in a shaking bath (Selecta, Barcelona, Spain). Prior to the analysis, the extracts were filtered using nitrocellulose syringe filters (0.45 $\mu \mathrm{m}$ pore size). Hg was determined by Cold Vapor Atomic Fluorescence Spectroscopy (AFS-CV) with Millennium 
Table 2. Total $\mathrm{Hg}$ and Different Extractable $\mathrm{Hg}$ Concentrations in Soils $\left(\mu \mathrm{g} \mathrm{Hg} \mathrm{g}^{-1}\right.$ soil) from the Different Sampling Sites in the Almadenejos Precinct and Surrounding Areas ${ }^{a}$

\begin{tabular}{|c|c|c|c|c|c|c|c|}
\hline sampling site & total $\mathrm{Hg}$ & organic $\mathrm{Hg}$ & USGS & EPA & $\mathrm{AcNH}_{4}(\mathrm{pH}=7)$ & $\mathrm{AcNH}_{4}(\mathrm{pH}=4.5)$ & EDTA $0.05 \mathrm{M}$ \\
\hline $\begin{array}{l}\text { E1. Almadenejos precinct } \\
\text { (above the furnace) }\end{array}$ & $4830 \pm 520$ & $16.1 \pm 0.1$ & $5.17 \pm 0.05$ & $6.28 \pm 0.04$ & $3.84 \pm 0.08$ & $87 \pm 2$ & $93.66 \pm 0.03$ \\
\hline $\begin{array}{l}\text { E2. Almadenejos precinct } \\
\text { (next to the furnace) }\end{array}$ & $4260 \pm 467$ & $2.83 \pm 0.06$ & $4.36 \pm 0.07$ & $7.06 \pm 0.01$ & $2.25 \pm 0.08$ & $25.999 \pm 0.005$ & $76 \pm 2$ \\
\hline E3. Mine entrance & $1995 \pm 134$ & $0.84 \pm 0.02$ & $1.05 \pm 0.02$ & $1.73 \pm 0.01$ & $0.4686 \pm 0.0005$ & $5.70 \pm 0.02$ & $11.2 \pm 0.2$ \\
\hline $\begin{array}{l}\text { E4. Almadenejos precinct } \\
\text { (wall) }\end{array}$ & $1340 \pm 99$ & $0.11 \pm 0.03$ & $0.081 \pm 0.004$ & $0.110 \pm 0.009$ & $0.229 \pm 0.005$ & $0.234 \pm 0.003$ & $1.7 \pm 0.7$ \\
\hline E5. Gargantiel & $2 \pm 1$ & $<$ LOD & $<$ LOD & $0.0024 \pm 0.0009$ & $<$ LOD & $0.0179 \pm 0.0009$ & $0.033 \pm 0.002$ \\
\hline
\end{tabular}

Merlin equipment (PS Analytical, Orpington, UK). With this method, mercury is oxidized with a bromide/bromate mixture and then reduced with $\mathrm{Sn}$ (II) chloride. Free mercury atoms in a carrier gas are excited by an ultraviolet light source at a wavelength of $254 \mathrm{~nm}$. By measuring the radiation emitted, the specific element being measured is quantified.

c) The United States Environmental Protection Agency method (EPA 1312), known as the Synthetic Precipitation Leach Procedure (SPLP), determines the mobility of inorganic mercury present in waste materials in acid conditions caused by acidic rain. Five $\mathrm{g}$ of soil of each sample was processed with 100 $\mathrm{mL}$ of the extracting solution $\left(\mathrm{H}_{2} \mathrm{SO}_{4}: \mathrm{HNO}_{3}\right.$ in a proportion of $60: 40$ at a $\mathrm{pH}$ adjusted to 4.2 ), which is considered comparable to that of expected acid rain. The extraction was performed at $25{ }^{\circ} \mathrm{C}$ in a bath for $18 \mathrm{~h}$ with shake at $30 \mathrm{rpm}$. The extracts were filtered with borosilicate glass fiber filters $(0.7 \mu \mathrm{m}$ pore size) and analyzed by AFS-CV, as described above.

d) Other extraction procedures were performed by changing only the extracting solution and the conditions of the extractions to $2 \mathrm{~h}$ at $25{ }^{\circ} \mathrm{C}$, shaking at $50 \mathrm{rpm}$. The extractants were $0.05 \mathrm{~mol} \mathrm{~L}^{-1}$ ethylenediaminetetraacetic acid (EDTA) at $\mathrm{pH}=4.5$, ammonium acetate at $\mathrm{pH}=7$, and ammonium acetate at $\mathrm{pH}=4.5$. All solutions were filtered with $0.45 \mu \mathrm{m}$ Teflon filters prior to analysis. AFS-CV was used as described above to determine the $\mathrm{Hg}$ concentration.

Three independent replicates for each sample were analyzed, and a blank analysis of each extraction procedure was then subtracted.

\section{RESULTS AND DISCUSSION}

3.1. Hg Determination in Soils. Several extraction methods were carried out in order to determine diverse metal fractions in soils and identify plant-available forms of $\mathrm{Hg}$ in soils for correlating with the synthesized PCs. The results for the different $\mathrm{Hg}$ fractions in soils are given in Table 2. For total $\mathrm{Hg}$ concentration, soils around Almadenejos have between 4,830 and $1,340 \mu \mathrm{g} \mathrm{Hg} \mathrm{g}^{-1}$ soil, which is consistent with the studies by Gray et al. ${ }^{18}$ and Martinez-Coronado et al. ${ }^{11}$ The most contaminated soils are those from the furnace ruins (sampling sites E1 and E2), which have up to 1,960 times the $\mathrm{Hg}$ concentration of the control soil sampled at Gargantiel (sampling site E5), which has $2 \mu \mathrm{g} \mathrm{Hg} \mathrm{g}^{-1}$ soil. As Senesi et al. $^{41}$ pointed out, the usual concentrations of nonpolluted soils fall within the range $0.01-0.03 \mu \mathrm{g} \mathrm{Hg} \mathrm{g}^{-1}$. Therefore, the soil of Gargantiel cannot be considered uncontaminated. Soils from the mine entrance (sampling site E3) also have a high level of $\mathrm{Hg}, 1,995 \mu \mathrm{g} \mathrm{Hg} \mathrm{g}^{-1}$ soil, more than the zone of the Almadenejos precinct next to the village (sampling site E4), with $1,340 \mu \mathrm{g} \mathrm{Hg} \mathrm{g}^{-1}$ soil. Given these results, it is not exaggerated to consider the Almadén mining district one of the most Hg-contaminated places in the world and the "Cerco de Almadenejos", the most contaminated place in the Almadén area.

However, despite the very high $\mathrm{Hg}$ concentration in these soils, mercury associated with water-soluble phases and exchangeable forms is very low. For all the different extraction methodologies, $\mathrm{Hg}$ concentration at the different sites correlates with total $\mathrm{Hg}$ concentration, being the furnace ruins the site with the highest level of mercury. The highest amounts of $\mathrm{Hg}$ were extracted with EDTA, as Table 2 shows. The carbonate bound fraction, which is determined with ammonium acetate at $\mathrm{pH}$ value of 4.5 , is also very high. On the contrary, the ammonium acetate extraction at $\mathrm{pH}=7$ that determined the exchangeable and weakly adsorbed fraction was the least effective extraction reagent. The EPA method, which could be associated with the $\mathrm{Hg}$ extractable in acidic conditions caused by acid rain, and the USGS method, which simulates the water leachability of geological materials, provided slightly higher values.

Determinations of total or inorganic mercury do not provide adequate information about its impact on the environment. In particular, organic mercury compounds are generally more toxic than inorganic mercury salts, due to their higher solubility in lipids, which increases the potential for biological uptake and bioconcentration. Organic mercury determined with the methodology described above ranges from $16.1 \mu \mathrm{g} \mathrm{Hg} \mathrm{g}^{-1}$ soil to nondetected values. The highest values were found in the furnace ruins, consistent with total $\mathrm{Hg}$ concentration. Nevertheless, only a maximum of $0.33 \%$ of the total mercury is in their organic forms. In this study, the most effective extractant was EDTA, with a maximum value in the furnace ruins zone (sampling site E1) of only $1.94 \%$ of $\mathrm{Hg}$ extracted. This highlights the immobility of $\mathrm{Hg}$ in this mining zone, where, despite soils' extremely high concentrations of mercury, only small fractions could be solubilized and were therefore available for plants. Thus, most of the mercury in the soils of Almadenejos could be in the form of cinnabar ( $\mathrm{HgS}$ ) particles which are not phytoavailable for plants, as was indicated by Higueras et al. ${ }^{9}$

3.2. Hg Determination in Plants. To determine the total $\mathrm{Hg}$ concentration in plants, both aerial parts and roots were analyzed. The results are shown in Table $3 . \mathrm{Hg}$ concentration in plants of various origins was consistent with its concentration in related soils. As was foreseeable, plants from above the furnace ruins (zone E1) had more mercury, 76 and $74 \mu \mathrm{g} \mathrm{Hg}$ $\mathrm{g}^{-1}$ for roots and aerial parts, respectively, than plants from Gargantiel (zone E5), with values of 0.14 and $0.12 \mu \mathrm{g} \mathrm{Hg} \mathrm{g}^{-1}$ in roots and aerial parts, respectively. In general, plants from the highest contaminated zones accumulate more mercury in roots than in aerial parts, although the value of $\mathrm{Hg}$ concentration in 
Table 3. Concentrations of Total $\mathrm{Hg}$ in Plants $\left(\mu \mathrm{g} \mathrm{Hg} \mathrm{g}^{-1}\right.$ fresh weight) in Aerial Parts and Roots of Asparagus acutifolius from Different Sites of the Almadenejos Precinct and the Surrounding Areas ${ }^{a}$

\begin{tabular}{lcc}
\multicolumn{1}{c}{ sampling site } & $\mathrm{Hg}$ concn $\left(\mu \mathrm{g} \mathrm{Hg} \mathrm{g}^{-1} \mathrm{FW}\right)$ \\
\cline { 2 - 3 } & aerial parts & roots \\
E1. Almadenejos precinct (above the furnace & $74 \pm 8$ & $76 \pm 43$ \\
ruins) & & \\
E2. Almadenejos precinct (next to the & $29 \pm 5$ & $66 \pm 11$ \\
$\quad$ furnace ruins) & & \\
E3. Mine entrance & $2.9 \pm 0.1$ & $5 \pm 1$ \\
E4. Almadenejos precinct (wall) & $1.4 \pm 0.1$ & $1.7 \pm 0.7$ \\
E5. Gargantiel & $0.12 \pm 0.04$ & $0.14 \pm 0.02$
\end{tabular}

${ }^{a}$ Values are the mean \pm standard deviation of three replicates.

roots from the E1 zone has a very high associated error which affects the interpretation. In general, the accumulation of more mercury in roots than in aerial parts can be seen as a strategy for protecting the more sensitive aerial parts from the deleterious effects induced by metal stress. Therefore, mercury ions are preferably retained in root tissues, and only small portions are transferred to leaves. ${ }^{25,28,29}$ However, it has to be remarked that the atmospheric $\mathrm{Hg}$ pollution in these zones is very high as indicated by Higueras et al., ${ }^{19}$ and, therefore, possibly part of the mercury found in the aerial parts of plants could come from atmospheric deposition phenomena. ${ }^{42}$ In general, the correlation between the total $\mathrm{Hg}$ in plants, in both aerial parts and roots, and the $\mathrm{Hg}$ obtained by any of the different extraction procedures is close to linearity.

3.3. Analysis of Phytochelatins and $\mathrm{Hg}$-Phytochelatin Complexes. To explore a way of following heavy metal stress response, the variation in thiol composition was analyzed, following the method of Dago et al. ${ }^{34} \mathrm{Six}$ biothiols were determined (GSH, $\gamma$-Glu-Cys, and $\mathrm{PC}_{2-5}$ ), as well as $\mathrm{Hg}$ complexes of $\mathrm{GSH}$ and $\mathrm{PC}_{2}$. With this methodology, $\mathrm{Hg}$ complexes with other PCs $\left(\mathrm{PC}_{3}, \mathrm{PC}_{4}, \mathrm{PC}_{5}\right)$ could be detected, but they could not be individually identified as they were clustered at the same retention time. ${ }^{34}$ With the aim of analyzing PCs and their $\mathrm{Hg}$ complexes, cleaned up and preconcentrated extracts of each sample were injected into the chromatograph, and results of aerial parts and roots were analyzed separately. Figure 2 shows, as an example, a chromatogram of roots of Asparagus acutifolius from the Almadenejos precinct (zone E1). Peaks were identified by

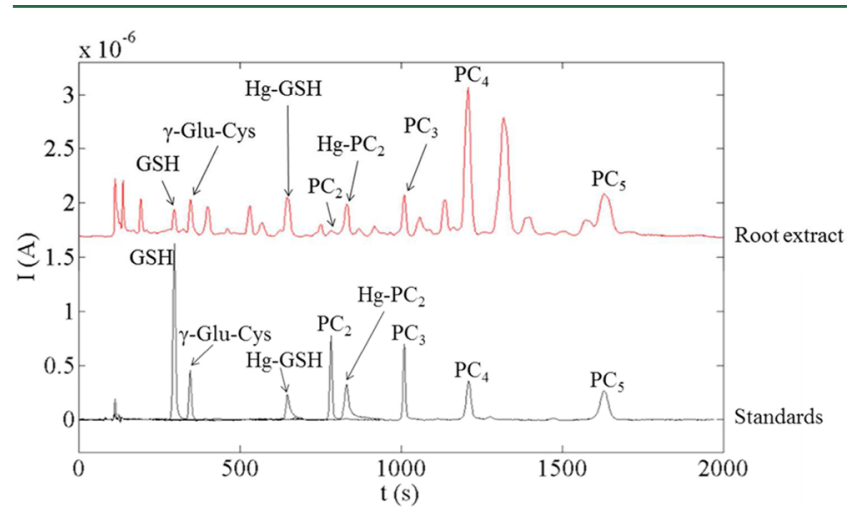

Figure 2. Chromatogram of root extracts of Asparagus acutifolius from above the furnace in the Almadenejos precinct zone (zone E1) compared with a chromatogram of standards $\left(5 \times 10^{-5} \mathrm{~mol} \mathrm{~L}^{-1}\right)$. comparing the retention times obtained with the injection of standards. External calibration curves for each thiol were used for quantification. Nevertheless, in the case of $\mathrm{Hg}$ complexes, no commercial standards were available, and external calibration curves were done by mixing different concentrations of thiols with an excess of $\mathrm{Hg}$. Thus, the concentration of the complex was the same as the concentration of the thiol added, while taking into account that with these injections only the complex peak appears in the chromatogram. This ensures that all the thiol is complexed. Thus, due to its ML stoichiometry, determined in previous studies by Dago et al., ${ }^{34}$ the concentration of the complex can be regarded as the same as the concentration of thiol present in the mixture. Figure 3
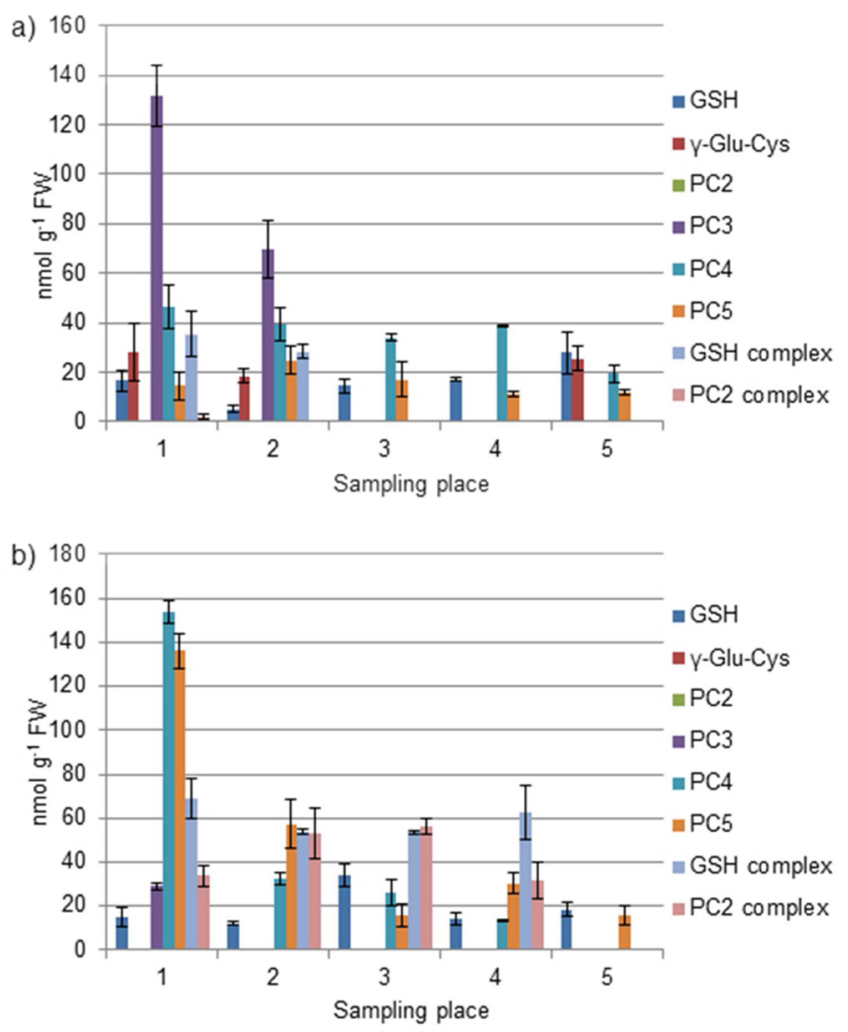

Figure 3. Quantification of thiols and some of its $\mathrm{Hg}$ complexes in Asparagus acutifolius aerial parts (a) and roots (b), grown in the different sampling places: (1) above a furnace ruins, (2) next to a furnace ruins, (3) in the mine entrance, (4) in the wall of the Almadenejos precinct, (5) Gargantiel.

shows the average and the standard deviation obtained for three replicates of plants from the sampling sites. At first glance, samples with more mercury synthesize more phytochelatins as a response to metal toxicity. It is also noticeable that longer PCs are more abundant in roots than in aerial parts, indicating that PCs, which are mainly synthesized in roots, are not compounds for long-distance root-to-shoot $\mathrm{Hg}$ transfer. ${ }^{26}$ Moreover, longer PCs increase their concentration with increasing metal concentration. However, GSH is more concentrated in aerial parts than in roots, as shown by Sobrino-Plata et al., ${ }^{30}$ who pointed out that GSH is synthesized in shoots and then exported to roots, where it could be converted into PCs. Furthermore, GSH generally reduces its concentration with an increase of $\mathrm{Hg}$ concentration, because other longer-chain thiols are formed using GSH as the substrate. 
Turning to the results from the analyses of aerial parts (Figure 3a), plants from the furnace ruins (sampling sites E1 and E2) generated an extremely large quantity of $\mathrm{PC}_{3}$ (the maximum concentration of $\mathrm{PC}_{3}$ is $132 \pm 12 \mathrm{nmol} \mathrm{g}{ }^{-1}$ fresh weight in the extract of the aerial parts of E1 zone), as well as a relatively high level of the GSH complex, in comparison with plants from other locations. These findings are consistent with the higher concentration of $\mathrm{Hg}$ in soils and also in plants. The concentrations of other thiols did not increase visibly. However, $\mathrm{PC}_{4}, \gamma$-Glu-Cys, and the GSH complex also reached their maxima in this extract, with $46 \pm 9,28 \pm 12$, and $35 \pm 9 \mathrm{nmol}$ $\mathrm{g}^{-1}$ fresh weight, respectively. Unlike findings for other plant species, ${ }^{25,27} \mathrm{PC}_{2}$ is not the most abundant thiol in this case, either because it is the precursor molecule for the synthesis of longer-chain PCs or because it can be complexed by mercury. As explained in the literature on GSH, ${ }^{26}$ GSH concentration diminishes as the $\mathrm{Hg}$ concentration in leaves increases, since GSH is the substrate of the PC synthesis that is activated by a rise in metal concentration. A similar explanation could be accepted for $\mathrm{PC}_{2}$, as longer-chain $\mathrm{PCs}$ are formed by the successive addition of a Glu-Cys unit to the GSH or the precursor molecule $\left(\mathrm{PC}_{n-1}\right)$. Thus, for example, $\mathrm{PC}_{3}$ is formed by adding a Glu-Cys unit to a molecule of $\mathrm{PC}_{2}$. Aerial parts of plants from Gargantiel (sampling site E5) had small quantities of small thiols and also of some PCs. However, the presence of small amounts of $\mathrm{Hg}$ in plants and soils of this area, which could induce the synthesis of these PCs, is not a strange feature. For instance, Rauser ${ }^{14}$ detected the presence of $\mathrm{GSH}, \mathrm{PC}_{2}$, and $\mathrm{PC}_{3}$ in plants grown under normal conditions, with no heavy metal stress.

Concerning roots (Figure $3 \mathrm{~b}$ ), the extract with the most synthesized PCs came from above the furnace ruins (sampling site $\mathrm{E} 1$ ), and the most abundant thiol compounds in this extract were $\mathrm{PC}_{4}$ and $\mathrm{PC}_{5}$, with $154 \pm 5$ and $136 \pm 8 \mathrm{nmol} \mathrm{g}$ fresh weight, respectively. In the other root extracts, the concentrations of these thiol compounds diminished more or less in accord with the mercury concentration at the sampling site. In roots, $\mathrm{GSH}$ and $\mathrm{PC}_{2}$ complexes were relatively abundant at all sampling sites, with the exception of Gargantiel (sampling site E5). At sampling site $\mathrm{E} 1$, the $\mathrm{PC}_{2}$ complex was less abundant, perhaps because of the synthesis of longer-chain phytochelatins from $\mathrm{PC}_{2} . \mathrm{PC}_{3}$, which was the most abundant thiol in aerial parts, was only detected in the extract with the greatest $\mathrm{Hg}$ contamination (sampling site E1). The GSH complex shows a big difference between samples from Gargantiel (sampling site E5) and from the wall of the Almadenejos precinct (sampling site E4), with values of $12 \pm 2$ and $63 \pm 12 \mathrm{nmol} \mathrm{g}^{-1}$ fresh weight, respectively. Values then remained more or less constant for the other sampling sites. In root extracts from sampling site E5, very low concentrations of thiols were appreciated, with a maximum of $18 \pm 3 \mathrm{nmol} \mathrm{g}^{-1}$ fresh weight of GSH.

To sum up, the concentration of phytochelatins (PCs) and their $\mathrm{Hg}$ complexes were consistent with the amount of mercury found in soils; more phytoavailable $\mathrm{Hg}$ in soils produces more phytochelatins in plants as a response to metal toxicity. Longer-chain PCs were more abundant in roots than in aerial parts of plants, the opposite of GSH, which was more concentrated in aerial parts than in roots. Knowing that these thiols are mainly synthesized in roots, it is possible that the small GSH molecule could be transferred from roots to aerial parts, while the less mobile longer-chain PCs remain only in roots. When $\mathrm{Hg}$ concentration in soils increases, the concentrations of the longest-chain phytochelatins $\left(\mathrm{PC}_{3}, \mathrm{PC}_{4}\right.$, and $\mathrm{PC}_{5}$ ) increase, and, in consequence, smaller thiols such as $\mathrm{GSH}$ and $\mathrm{PC}_{2}$ decrease their concentrations because they serve as substrate for the synthesis of longer-chain PCs. Several differences between roots and aerial parts of plants were observed: in aerial parts the main $\mathrm{PC}$ synthesized is $\mathrm{PC}_{3}$, while in roots $\mathrm{PC}_{4}$ and $\mathrm{PC}_{5}$ have higher concentrations; and the $\mathrm{Hg}$ complexes of $\mathrm{GSH}$ and $\mathrm{PC}_{2}$ are more abundant in roots, as they accumulate more mercury than aerial parts.

With the aim of establishing the $\mathrm{Hg}$ extraction procedure that best relates the $\mathrm{Hg}$ concentration in soils with the synthesis of PCs, the total SH groups, calculated as Cys-Gly units in both aerial parts and roots, and the concentration of $\mathrm{Hg}$ determined in soils and plant tissues were correlated being $y$ the $\mathrm{Hg}$ concentration $\left(\mu \mathrm{g} \mathrm{Hg} \mathrm{g}^{-1}\right)$ and $x$ the Cys-Gly units (nmol g fresh weight) in all cases. The results of coefficients of determination are shown in Table 4. As it can be seen, the total

Table 4. Correlations between Total SH Groups ( $\mathrm{nmol} \mathrm{g}^{-1}$ ) in Aerial Parts and Roots and the Concentration of $\mathrm{Hg}(\mu \mathrm{g}$ $\left.\mathrm{g}^{-1}\right)$ in Plant Tissues and Soils ${ }^{a}$

$\begin{array}{lcc} & \text { aerial parts } & \text { roots } \\ \mathrm{Hg}(\text { plant tissues) } & 0.9584 & 0.6895 \\ \text { total } \mathrm{Hg}(\text { soil) } & 0.8743 & 0.6988 \\ \text { organic Hg (soil) } & 0.8296 & 0.9726 \\ \text { USGS extraction (soil) } & 0.9504 & 0.7152 \\ \mathrm{EPA} \text { extraction (soil) } & 0.8288 & 0.5249 \\ \mathrm{AcNH}_{4}(\mathrm{pH}=7)(\text { soil) } & 0.9981 & 0.8957 \\ \mathrm{AcNH}_{4}(\mathrm{pH}=4.5)(\text { soil) } & 0.9175 & 0.9790 \\ \mathrm{EDTA}^{(\text {soil })} & 0.9637 & 0.7389\end{array}$

${ }^{a}$ For $\mathrm{Hg}$ concentration in soils, different extractions were considered as explained in the text. Values shown correspond to determination coefficients $\left(R^{2}\right)$.

concentration of $\mathrm{Hg}$ in roots is not closely related with the synthesis of PCs. Contrarily, the extraction procedure that best relates the total concentration of $\mathrm{SH}$ groups in roots with the extractable $\mathrm{Hg}$ in soil is ammonium acetate extraction at $\mathrm{pH}$ 4.5 , giving a $R^{2}$ of 0.9790 and of 0.9175 , for roots and aerial parts, respectively. The correlation with the $\mathrm{Hg}$ concentration in roots is not as good as expected as a consequence of the large deviation of the value of $\mathrm{Hg}$ concentration in roots. In order to know which kind of thiols are more related to mercury contamination in soils, the total thiol content has been divided into several groups: GSH, $\gamma$-Glu-Cys, $\mathrm{PCs}\left(\mathrm{PC}_{3}+\mathrm{PC}_{4}+\mathrm{PC}_{5}\right)$, the Hg-GSH complex, and the $\mathrm{Hg}-\mathrm{PC}_{2}$ complex. Then, correlation with these groups with the ammonium acetate extraction at $\mathrm{pH}=4.5$ (the most correlated extraction procedure with total $\mathrm{SH}$ groups) were tested. The obtained $R^{2}$ coefficients for PCs $\left(\mathrm{PC}_{3}+\mathrm{PC}_{4}+\mathrm{PC}_{5}\right)$ were 0.8950 and 0.9859 for aerial parts and roots, respectively. The other $R^{2}$ coefficients were lower than 0.5 indicating that PCs are the best indicator of $\mathrm{Hg}$ effect in plants.

These findings highlight the important role of thiol compounds and their metal complexes in capturing and fixing $\mathrm{Hg}$ from soils, giving plants the capacity to deal with the heavy metal toxicity of polluted soils.

\section{AUTHOR INFORMATION}

\section{Corresponding Author}

*Phone: +34 9340215 45. Fax: +34 9340212 33. E-mail: cristina.arino@ub.edu. 


\section{Notes}

The authors declare no competing financial interest.

\section{ACKNOWLEDGMENTS}

The authors gratefully acknowledge financial support from the Spanish Ministerio de Ciencia e Innovación (projects CTQ2009-09471, CTQ2012-32863, and CGL2009-13171). Angela Dago acknowledges the University of Barcelona for a Ph.D. grant.

\section{REFERENCES}

(1) Lawrence, E.; Jackson, A. R. W.; Jackson, J. M. Longman Dictionary of Environmental Science; Longman: Harlow, 1998.

(2) Fitzgerald, W. F.; Clarkson, T. W. Mercury and monomethylmercury: present and future concerns. Environ. Health Perspect. 1991, 96, 159-166.

(3) Boening, D. W. Ecological effects, transport, and fate of mercury: a general review. Chemosphere 2000, 40, 1335-1351.

(4) Leermakers, M.; Baeyens, W.; Quevauviller, P.; Horvat, M. Mercury in environmental samples: Speciation, artifacts and validation. Trends Anal. Chem. 2005, 24, 383-393.

(5) Clarkson, T. W.; Magos, L. The toxicology of mercury and its chemical compounds. Crit. Rev. Toxicol. 2006, 36, 609-662.

(6) Hernández, A.; Jébrak, M.; Higueras, P.; Oyarzun, R.; Morata, D.; Munhá, J. The Almadén mercury mining district, Spain. Miner. Deposita 1999, 34, 539-548.

(7) Higueras, P.; Oyarzun, R.; Lillo, J.; Morata, D. Intraplate mafic magmatism, degasification, and deposition of mercury: The giant Almadén mercury deposit (Spain) revisited. Ore Geol. Rev. 2013, 51, 93-102.

(8) Higueras, P.; Oyarzun, R.; Lillo, J.; Sánchez-Hernández, J. C.; Molina, J. A.; Esbrí, J. M.; Lorenzo, S. The Almadén district (Spain): anatomy of one of the world's largest Hg-contaminated sites. Sci. Total Environ. 2006, 356, 112-124.

(9) Higueras, P.; Oyarzun, R.; Biester, H.; Lillo, J.; Lorenzo, S. A first insight into mercury distribution and speciation in the Almaden mining district, Spain. J. Geochem. Explor. 2003, 80, 95-104.

(10) Gray, J. E.; Hines, M. E.; Higueras, P. L.; Adatto, P.; Lasorsa, B. $\mathrm{K}$. Mercury speciation and microbial transformations in mine wastes, stream sediments, and surface waters at the Almadén Mining District, Spain. Environ. Sci. Technol. 2004, 38, 4285-4292.

(11) Martínez-Coronado, A.; Oyarzun, R.; Esbrí, J. M.; Llanos, W.; Higueras, P. Sampling high to extremely high $\mathrm{Hg}$ concentrations at the Cerco de Almadenejos, Almadén mining district (Spain): The old metallurgical precinct (1794 to $1861 \mathrm{AD}$ ) and surrounding areas. J. Geochem. Explor. 2011, 109, 70-77.

(12) Salt, D. E.; Smith, R. D.; Raskin, I. Phytoremediation. Annu. Rev. Plant Physiol. Plant Mol. Biol. 1998, 49, 643-668.

(13) Padmavathiamma, P. K.; Li, L. Y. Phytoremediation technology: Hyperaccumulation metals in plants. Water, Air, Soil Pollut. 2007, 184, $105-126$.

(14) Rauser, W. E. Phytochelatins and related peptides. Plant Physiol. 1995, 109, 1141-1149.

(15) Grill, E.; Winnacker, E.-L.; Zenk, M. H. Phytochelatins, a class of heavy-metal-binding peptides from plants, are functionally analogous to metallothioneins. Proc. Natl. Acad. Sci. U.S.A. 1987, 84, 439-443.

(16) Cobbett, C. S. Phytochelatins and their roles in heavy metal detoxification. Plant Physiol. 2000, 123, 825-832.

(17) Cobbett, C.; Goldsbrough, P. Phytochelatins and metallothioneins: Roles in heavy metal detoxification and homeostasis. Annu. Rev. Plant Biol. 2002, 53, 159-182.

(18) Ferrara, R.; Maserti, B. E.; Andersson, M.; Edner, H.; Ragnarson, P.; Svanberg, S.; Hernández, A. Atmospheric mercury concentrations and fluxes in the Almadén district (Spain). Atmos. Environ. 1998, 32, 3897-3904.

(19) Higueras, P.; Esbrí, J. M.; Oyarzun, R.; Llanos, W.; MartínezCoronado, A.; Lillo, J.; López-Berdonces, M. A.; García-Noguero, E.
M. Industrial and natural sources of gaseous elemental mercury in the Almadén district (Spain): An updated report on this issue after the ceasing of mining and metallurgical activities in 2003 and major land reclamation works. Environ. Res. 2013, 125, 197-208.

(20) Berzas Nevado, J. J.; García Bermejo, L. F.; Rodríguez MartínDoimeadios, R. C. Distribution of mercury in the aquatic environment at Almadén, Spain. Environ. Pollut. 2003, 122, 261-271.

(21) Rodríguez Martín-Doimeadios, R. C.; Wasserman, J. C.; García Bermejo, L. F.; Amouroux, D.; Berzas Nevado, J. J.; Donard, O. F. X. Chemical availability of mercury in stream sediments from the Almadén area, Spain. J. Environ. Monit. 2000, 2, 360-366.

(22) Millán, R.; Gamarra, R.; Schmid, T.; Sierra, M. J.; Quejido, A. J.; Sánchez, D. M.; Cardona, A. I.; Fernández, M.; Vera, R. Mercury content in vegetation and soils of the Almadén mining area (Spain). Sci. Total Environ. 2006, 368, 79-87.

(23) Molina, J. A.; Oyarzun, R; Esbrí, J. M.; Higueras, P. Mercury accumulation in soils and plants in the Almadén mining district, Spain: one of the most contaminated sites on Earth. Environ. Geochem. Health 2006, 28, 487-498.

(24) Rodríguez, L.; Rincón, J.; Asencio, I.; Rodríguez-Castellanos, L. Capability of selected crop plants for shoot mercury accumulation from polluted soils: phytoremediation perspectives. Int. J. Phytoremediat. 2007, 9, 1-13.

(25) Iglesia-Turiño, S.; Febrero, A.; Jauregui, O.; Caldelas, C.; Araus, J. L.; Bort, J. Detection and quantification of unbound phytochelatin 2 in plant extracts of Brassica napus grown with different levels of mercury. Plant Physiol. 2006, 142, 742-749.

(26) Chen, L.; Yang, L.; Wang, Q. In vivo phytochelatins and Hgphytochelatin complexes in Hg-stressed Brassica chinesis L. Metallomics 2009, 1, 101-106.

(27) Carrasco-Gil, S.; Álvarez-Fernández, A.; Sobrino-Plata, J.; Millán, R; Carpena-Ruiz, R. O.; Leduc, D. L.; Andrews, J. C.; Abadía, J.; Hernández, L. E. Complexation of $\mathrm{Hg}$ with phytochelatins is important for plant $\mathrm{Hg}$ tolerance. Plant Cell Environ. 2011, 34, 778791.

(28) Válega, M.; Lima, A. I. G.; Figueira, E. M. A. P.; Pereira, E.; Pardal, M. A.; Duarte, A. C. Mercury intracelular partitioning and chelation in a salt marsh plant, Halimione portucaloides (L.) aellen: Strategies underlying tolerance in environmental exposure. Chemosphere 2009, 74, 530-536.

(29) Rellán-Álvarez, R.; Ortega-Villasante, C.; Álvarez-Hernández, A.; Del Campo, F. F.; Hernández, L. E. Stress responses of Zea mays to cadmium and mercury. Plant Soil 2006, 279, 41-50.

(30) Sobrino-Plata, J.; Ortega-Villasante, C.; Flores-Cáceres, M. L.; Escobar, C.; Del Campo, F. F.; Hernández, L. E. Differential alterations of antioxidant defenses as bioindicators of mercury and cadmium toxicity in alfalfa. Chemosphere 2009, 77, 946-954.

(31) Chekmeneva, E.; Díaz-Cruz, J. M.; Ariño, C.; Esteban, M. Binding of $\mathrm{Hg}^{2+}$ with phytochelatins: Study by differential pulse voltammetry on rotating Au-disk electrode, electrospray ionization mass-spectrometry and isothermal titration calorimetry. Environ. Sci. Technol. 2009, 43, 7010-7015.

(32) Chekmeneva, E.; Díaz-Cruz, J. M.; Ariño, C.; Esteban, M. Binding of $\mathrm{Hg}^{2+}$ by Cys, Cys-Gly and reduced glutathione: Study by differential pulse voltammetry on rotating Au-disk electrode, electrospray ionization mass-spectrometry and isothermal titration calorimetry. J. Electroanal. Chem. 2010, 644, 20-24.

(33) Dago, A.; González-García, O.; Ariño, C.; Díaz-Cruz, J. M.; Esteban, M. Liquid chromatographic analysis of $\mathrm{Hg}$ (II) binding by thiol-rich peptides using both UV-vis and electrochemical detection. J. Chromatogr. A 2009, 1216, 6752-6757.

(34) Dago, A.; González-García, O.; Ariño, C.; Díaz-Cruz, J. M.; Esteban, M. Characterization of $\mathrm{Hg}$ (II) binding with different length phytochelatins using liquid chromatography and amperometric detection. Anal. Chim. Acta 2011, 695, 51-57.

(35) Dago, A.; Ariño, C.; Díaz-Cruz, J. M.; Esteban, M. Analysis of phytochelatins and Hg-phytochelatin complexes in Hordeum vulgare plants stressed with $\mathrm{Hg}$ and $\mathrm{Cd}$ : HPLC study with amperometric 
detection. Int. J. Environ. Anal. Chem. 2013, http://dx.doi.org/10. 1080/03067319.2013.864649.

(36) Dago, A.; González, I.; Ariño, C.; Díaz-Cruz, J. M.; Esteban, M. Chemometrics applied to the analysis of induced phytochelatins in Hordeum vulgare plants stressed with various toxic non-essential metals and metalloids. Talanta 2014, 118, 201-209.

(37) Van Reeuwijk, L. P. Procedures for Soil Analysis. Technical Paper 9. 6th ed.; ISRIC: 2002.

(38) Walkley, A.; Black, I. A. An examination of the Degtjareff method for determining soil organic matter, and a proposed modification of the chromic acid titration method. Soil Sci. 1934, 37, $29-38$.

(39) Válega, M.; Abreu, S.; Pato, P.; Rocha, L.; Gomes, A. R.; Pereira, M. E.; Duarte, A. C. Determination of organic mercury in biota, plants and contaminated sediments using a thermal atomic absorption spectrometry technique. Water, Air, Soil Pollut. 2006, 174, 223-234.

(40) Hageman, P. L. A simple field leach test to assess potential leaching of soluble constituents from mine wastes, soils, and other geologic materials. USGS Fact Sheet 2005, 2005-3100.

(41) Senesi, S. S.; Baldassarre, G.; Senesi, N.; Radina, B. Trace element inputs into soils by anthropogenic activities and implications for human health. Chemosphere 1999, 39, 343-377.

(42) Higueras, P.; Amorós, J. A.; Esbrí, J. M.; García-Navarro, F. J.; Pérez de los Reyes, C.; Moreno, G. Time and space variations in mercury and other trace element contents in olive tree leaves from the Almadén Hg-mining district. J. Geochem. Explor. 2012, 123, 143-151. 